J. Environ. Sci.

Institute of Environmental Studies and Research - Ain Shams University

\title{
ASSESSMENT OF THE PHYSICO-CHEMICAL PROPERTIES OF PRODUCED WATER FROM SARIR OIL FIELD IN SIRT BASIN, LIBYA
}

\begin{abstract}
Osamah M. A. Shahlol ${ }^{(1)}$; Heba Isawi ${ }^{(2)}$; Mohamed G. El-Malky ${ }^{(3)}$; Abd El-Hameed M. Al-Aassar ${ }^{(2)}$ and Adel Elzwi ${ }^{(4)}$

1) Faculty of Natural Resources, Al-Jufra University, Libya 2) Desert Research Center, Water Resources and Desert Soils Division, Hydrogeochemistry Dept., Water Desalination Unit, Egyptian Desalination Research Center of Excellence (EDRC), 1 Mathaf Al Mataria St., P.O.B. 11753, Cairo, Egypt 3) Institute of Environmental Studies and Research AinShams University, Abbassia, Cairo, Egypt .4) Reservoir Engineering superintendent, Arabian Gulf Oil Company ( AGOCO), Libya
\end{abstract}

\begin{abstract}
Production of oil and gas is accompanied with large volumes of produced water. Produced water is separated from the oil and gas and either re injected into the reservoir or discharged to the environment. Therefore, evaluation of produced water characteristics is very important and essential for both environmental and reservoir management. Produced water is a very complex mixture and contains different compounds that can have negative impact on the environment and economic problems associated with oil and gas production. This study has evaluated the characterization properties of produced water in Sarir oil field. The evaluation included the analysis of physio-chemical parameters e.g. pH, salinity, total dissolved solids (TDS), cations and anions constituents. These parameters show a wide variation from well to another.
\end{abstract}

Keyword: Physico-chemical properties; produced water; Sarir oil well; Sirit; Libya 


\section{INTRODUCTION}

The regular operations of gas and oil industry involve large amount of injected water to facilitate the petroleum recovery. This water is brought to the surface along with hydrocarbons (oil and gas), salt and other solutes, and is commonly known as "produced water" (PW). The composition depends on onsite natural geological information, containing various soluble mineral ions and being often acidic in nature. Fresh water is also used for desalting crude oil, sweetening of gas and other refinery processes, (Khatib and Verbeek, 2003).

Considering the global production of barrels of oil and related water, water to oil ratio (WOR) is approximately 3:1, (Arowoshola, et al., 2011). Global volume of PW generated is up to $39.5 \mathrm{Mm}^{3} /$ day, although the WOR is increasing. However, by 2025, due to the ageing wells, the WOR is expected to reach an average of $12(\mathrm{v} / \mathrm{v})$ for onshore crude oil resources. This will reinforce the growth of the market of PW's management (Arowoshola, et al., 2011).

Produced water is a complex mixture of dissolved and particulate organic and inorganic chemicals. The physical and chemical properties of produced water vary widely depending on the geologic age, depth, and geochemistry of the hydrocarbon-bearing formation, as well as the chemical composition of the oil and gas phases in the reservoir, and process chemicals added during production. Because no two produced waters are alike, region specific studies are needed to address the environmental risks from its discharge.

PW stream may contain various organic and inorganic compounds, harmless or toxic, which come naturally from the extraction wells, and others 
that are related to chemicals added for extraction purposes. PW quality varies appreciably according to the geochemistry of the producing formation, the type of hydrocarbon produced, and the characteristics of the producing well and the extracting method (Guerra, et al., 2011). Therefore, this stream properties and volume differ from one location to another, and even can vary over time, as the well ages. If PW meets appropriate water quality criteria, it could be reused again within the oil and gas production process, or even for purposes such as irrigation, livestock watering, aquifer storage, municipal and other industrial uses (Guerra, et al., 2011). To this end, PW analysis is needed to determine the suitable treatment of PW according to the requirements of each end-user and applications.

This study is aimed at determining the physico-chemical properties of produced water from Sarir oil field in Sirt basin in Libya, to determine the extent of compliance with standard and global best practices for disposal into the environment.

\section{MATERIALS AND METHODS}

1. Description of study area: The Sarir or, more specifically, the Sarir "C" field lies on the western edge of the Calanscio Sand Sea in southern Cyrenaica and is the largest oil field in Libya. It occurs at the southeastern margin of the Upper Cretaceous-Tertiary Sirte basin or embayment that contains all the major oil fields of Libya and is the most prolific oilproducing basin in North Africa, Figure_1. Other significant fields lying in the same basin are Amal, Gialo, Nasser (Zelten), Defa, Augila, Hateiba, Messla, Intisar A and D, Bu Attifel, Raguba, and Bahi. The Sarir "C" field, 
which is part of a complex of three fields, is $35 \mathrm{~m}(56 \mathrm{~km})$ long and $25 \mathrm{~m}$ $(40 \mathrm{~km})$ wide covering approximately $146 \mathrm{~m}^{2}\left(378 \mathrm{~km}^{2}\right)$. Estimated ultimate recovery from the " $\mathrm{C}$ " field is 6.5 billion of oil and from the "L" field 1.2 billion, ranking them as the 51st and 201st largest fields in the compilation of Carmalt and St. John (1986).

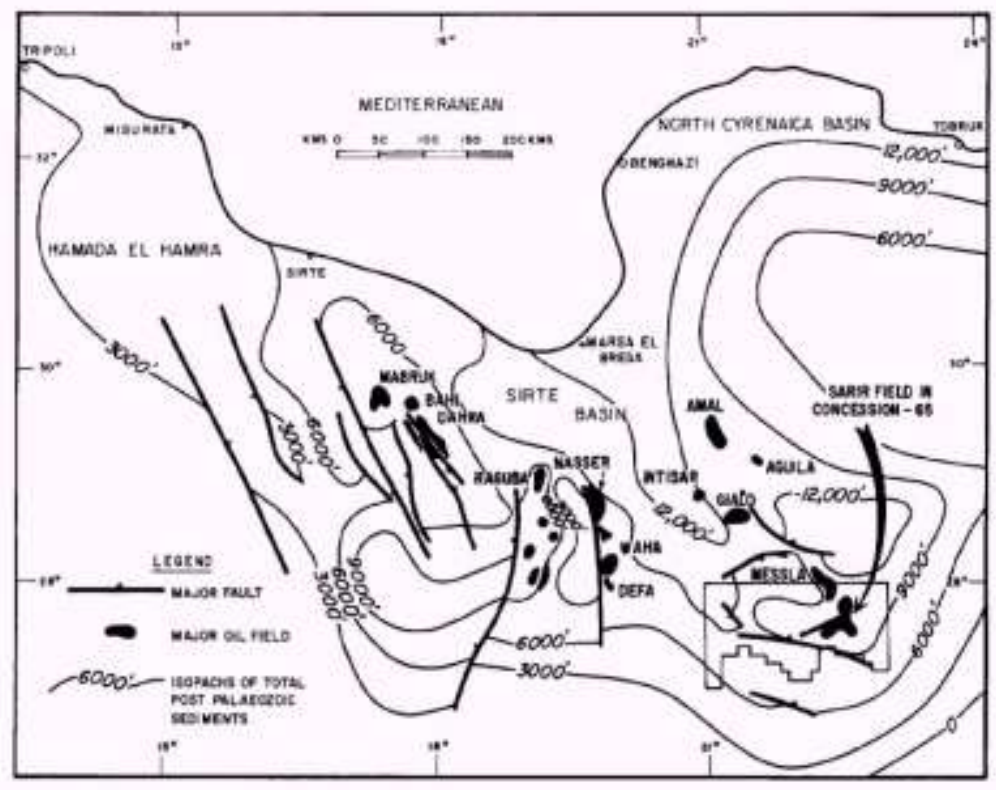

Fig. 1: Map of Sirt basin, Libya (Gillespie and Sanford, 1967).

2. Sample collection:The produced water samples have been obtained from the six Sarir oil field wells throughout periods of study 2015 and 2016 (GC1, GC2, GC3, GC4, GC5 and GC6) as shown in Figure 2. All the collected samples were preserved in accordance with guidelines and International Standards. All other QA/QC procedures relevant to sample collection, custody and analyses were strictly adhered to (APHA 1995; ASTM, 1979). 
J. Environ. Sci.

Institute of Environmental Studies and Research - Ain Shams University

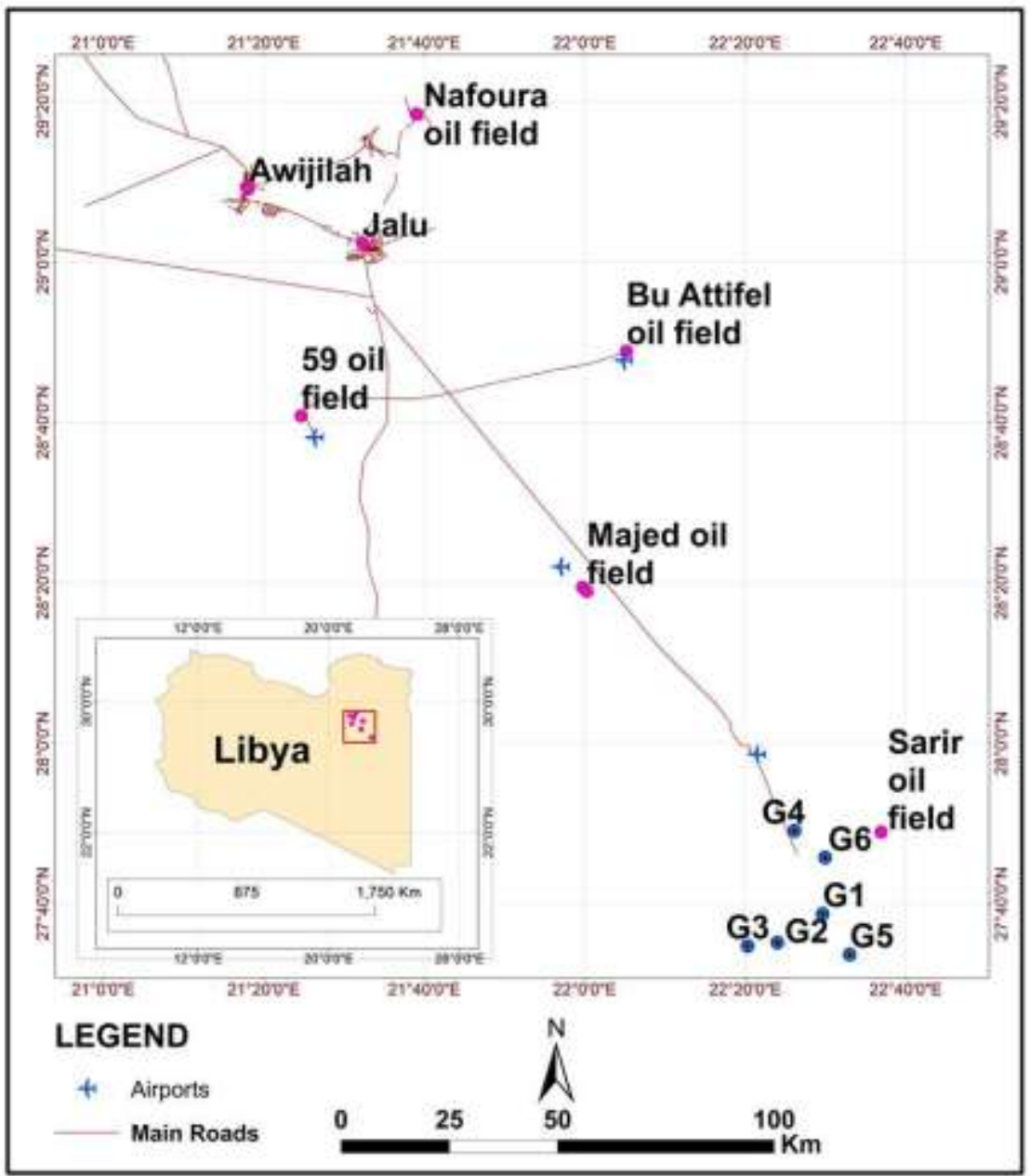

Fig. 2: Location of the six Sarir oil fields

3. Field and laboratory Analyses: The hydrogen ion concentration $(\mathrm{pH})$, electrical conductivity (EC), temperature, total dissolved solids (TDS) were measured electrometrically in the field using a multi-parameter data logger (Hanna model HI991300). Carbon dioxide was measured using titration method (APHA, 1995). The concentration of anions (chloride, 
sulfate, carbonate, bicarbonate, bromide, phosphate (as phosphorus) and nitrate) and cations (e.g. sodium, potassium, calcium, magnesium, lithium, barium and strontium were determined using Thermo/Dionex ICS-1100 Ion Chromatography System. The sulphide concentration was determined potentiometrically using Orion Versa star bench top meter with Orion Silver/Sulfide electrode (Thermo Scientific). Ionic Strength Adjustors (ISA) obtained from Thermo Scientific ${ }^{\mathrm{TM}}$ Orion $^{\mathrm{TM}}$. For measurement of heavy metals concentrations samples were pretreated with $2 \mathrm{ml}$ conc. $\mathrm{HNO}_{3}$ per liter of sample. The equipment was conditioned by auto-zeroing it with distilled water and with conc. $\mathrm{HNO}_{3}$. The pretreated sample was analyzed for heavy metals using the appropriate hollow cathode element of each metal of interest at the appropriate wavelength, lamp current, bandpass, and background correction. Heavy metals and silicon concentrations were determined using Atomic absorption spectrometer model (Perkin Elmer, model 2380). Bicarbonate is measured by titration with standardized sulfuric acid using methyl orange as indicator. Methyl orange turns yellow below $\mathrm{pH}$ 4.0. At this $\mathrm{pH}$, the carbonic acid decomposes to give carbon dioxide and water. Determination of oil and grease were achieved according to ASTM D 3921 method. High performance liquid chromatography (Agilent model 1100) was used to determine the concentration of organic acids. 
J. Environ. Sci.

Institute of Environmental Studies and Research - Ain Shams University

\section{RESULTS AND DISCUSSION}

1. Physio-chemical characterization of produce water: The physiochemical characterization parameters of produced water in Sarir oil field can be determined using the testing analytical data that obtained from oil field. The study included six oil wells are GC-1, GC-2, GC-3, GC-4, GC-5 and GC-6 as reported in Table 1.

These parameters include the physical properties e.g. $\mathrm{pH}$, conductivity, TDS and salinity, while the chemical properties represented by different parameters e.g. chloride, calcium, magnesium, phosphate, nitrate, oil and grease, etc. Test results of physico-chemical parameters are illustrated in Table 1 where, most of the parameters showed variation values throughout the different wells. 
Table 1: Physiochemical properties of produced water from six wells in the Sarir "C" fields.

\begin{tabular}{|c|c|c|c|c|c|c|c|}
\hline $\begin{array}{l}\text { Well No. } \\
\text { Parameter }\end{array}$ & Unit & GC-1 & GC-2 & GC-3 & GC-4 & GC-5 & GC-6 \\
\hline \multicolumn{8}{|c|}{ Chemical properties } \\
\hline Chloride & ppm & 93,378 & 122,496 & 124,284 & 122,825 & 120,883 & 118,537 \\
\hline Sulphate & ppm & 384 & 351 & 329 & 274 & 370 & 278 \\
\hline Bromide & ppm & 500 & 629 & 655 & 651 & 624 & 627 \\
\hline Nitrate & ppm & 0.41 & 0.22 & 0.26 & 0.26 & 0.22 & 0.2 \\
\hline Bicarbonate & ppm & 21 & 41 & 22 & 55 & 82 & 81 \\
\hline Boron & ppm & 24 & 28 & 27 & 31 & 35 & 29 \\
\hline Lithium & ppm & 9.5 & 9.2 & 10.1 & 14.2 & 8.3 & 13.2 \\
\hline Barium & ppm & 8 & 9 & 10 & 12 & 8 & 9 \\
\hline Strontium & ppm & 359 & 419 & 449 & 486 & 427 & 452 \\
\hline Calcium & ppm & 12,119 & 13,357 & 14,637 & 15,810 & 13,486 & 15,480 \\
\hline Magnesium & ppm & 1,291 & 1,831 & 1,758 & 1,673 & 1,785 & 1,619 \\
\hline Sodium & ppm & 42,989 & 59,342 & 58,513 & 56,728 & 57,482 & 53,233 \\
\hline Potassium & ppm & 672 & 611 & 603 & 739 & 589 & 752 \\
\hline Iron & ppm & 99 & 94 & 101 & 154 & 95 & 220 \\
\hline Copper & ppm & 1 & 1 & 1 & 1 & 1 & 1 \\
\hline Zinc & ppm & 2 & 3 & 5 & 3 & 5 & $<1$ \\
\hline Manganese & ppm & 63 & 63 & 72 & 90 & 59 & 84 \\
\hline Aluminium & ppm & $<3$ & $<3$ & $<3$ & $<3$ & $<3$ & $<3$ \\
\hline Phosphorus & ppm & $<3$ & $<3$ & $<3$ & $<3$ & $<3$ & $<3$ \\
\hline Silicon & ppm & 21 & 17 & 17 & 19 & 17 & 19 \\
\hline Carbon dioxide & ppm & 50 & 58 & 116 & 59 & 78 & 77 \\
\hline Sulphide & ppm & $<0.1$ & $<0.1$ & $<0.1$ & $<0.1$ & $<0.1$ & $<0.1$ \\
\hline Formate & ppm & $<1$ & $<1$ & $<1$ & $<1$ & $<1$ & $<1$ \\
\hline Acetate & ppm & 41 & 18 & 15 & 26 & 66 & 81 \\
\hline Propionate & ppm & 3.4 & $<1$ & $<1$ & 1.7 & 5.9 & 13 \\
\hline Butyrate & ppm & $<2$ & $<2$ & $<2$ & $<2$ & $<2$ & $<2$ \\
\hline Iso-valerate & ppm & $<2$ & $<2$ & $<2$ & $<2$ & $<2$ & $<2$ \\
\hline Oil and grease & ppm & 55 & 45 & 40 & 46 & 55 & 47 \\
\hline \multicolumn{8}{|c|}{ Physical properties } \\
\hline $\mathbf{P H}$ & & 5.6 & 6.07 & 5.46 & 6.14 & 6.2 & 6.2 \\
\hline TDS & ppm & 151,875 & 199,216 & 201,427 & 199,461 & 195,804 & 191,304 \\
\hline Conductivity & $\mathrm{mS} / \mathrm{cm}$ & 166,600 & 342,000 & 471,000 & 294,800 & 182,900 & 294,500 \\
\hline Salinity, NaCl & ppm & 154,260 & 202,363 & 205,317 & 202,906 & 199,698 & 195,823 \\
\hline
\end{tabular}


From the physical properties, the conductivity ranges from 166,000 ppm in GC-1 to the highest value 471,000 ppm in GC-3, Figure 3.

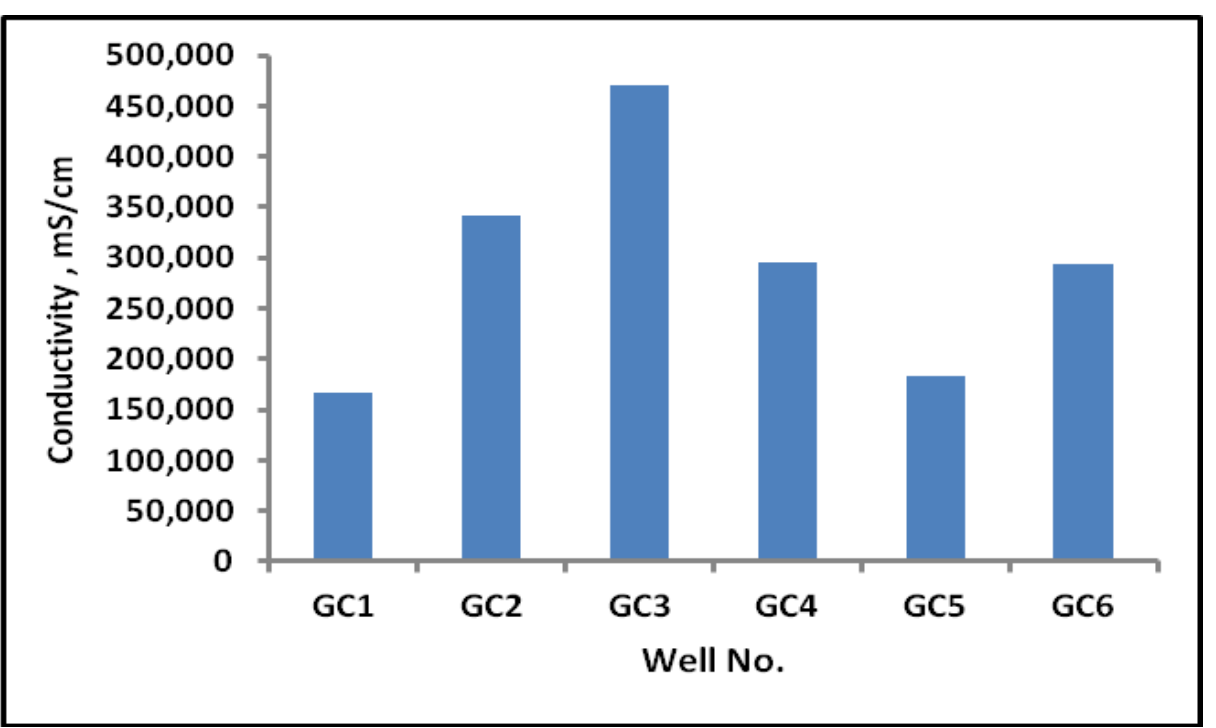

Fig. 3: Conductivity $(\mathrm{mS} / \mathrm{cm})$ of produced water from six wells in the Sarir "C" fields.

Total dissolved solid (TDS) is a reflection of suspended and dissolved ions inherent in the produced water. The value of TDS ranged from 151,875 ppm to $201,427 \mathrm{ppm}$. It is an important indicator of the usefulness of water for various applications. The concentration of the total dissolved solids which include heavy metals and dissolved salts, can be reduced by the installation of proper treating facilities, Figure 4. 


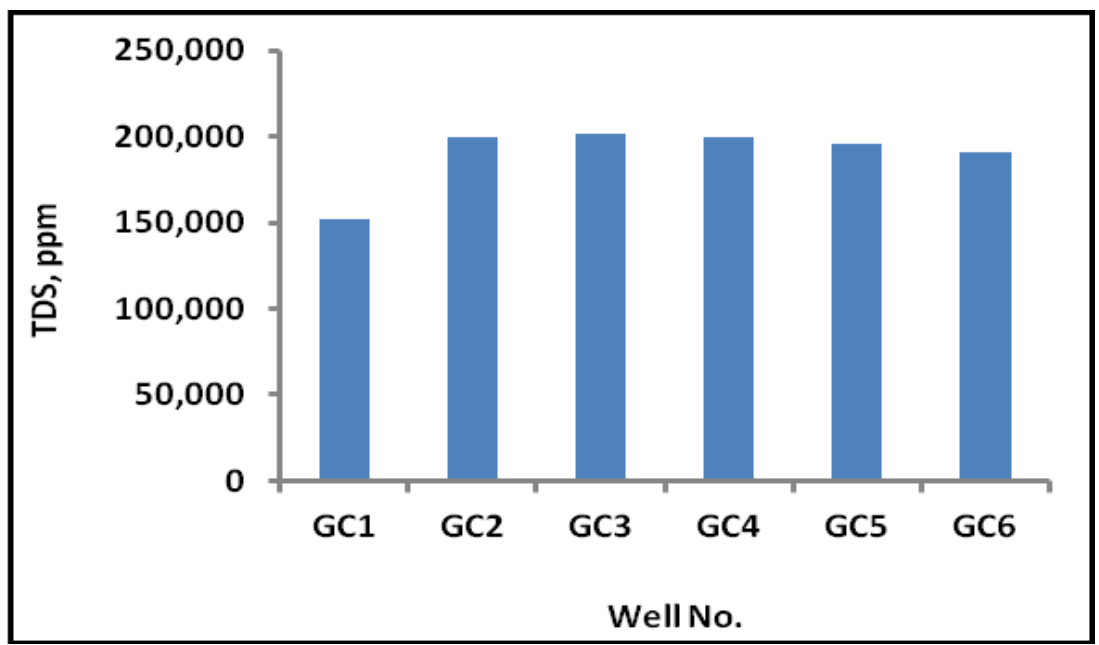

Fig. 4: TDS (ppm) of produced water from six wells in the Sarir "C" fields.

Figure 5 depicts the variable values for $\mathrm{pH}$, where the highest value of $\mathrm{pH}$ recorded in GC-5 and GC-6 is 6.2 and the lowest one in GC-3 is 5.46.

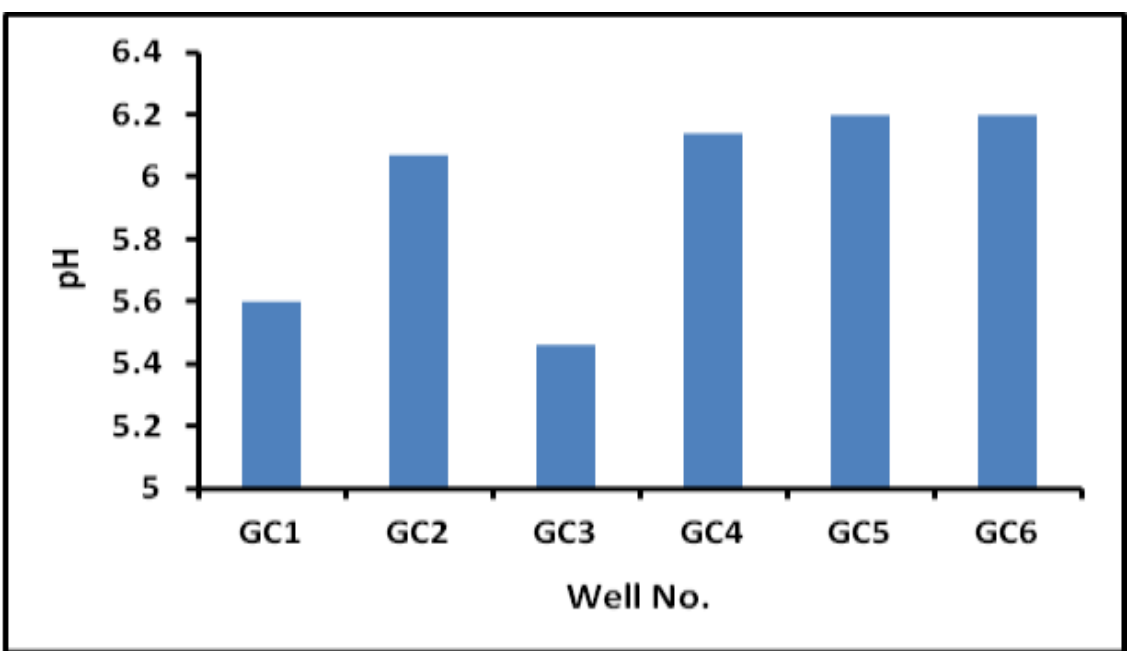

Fig. 5: $\mathrm{pH}$ of produced water from six wells in the Sarir "C" fields. 
Salinity is defined as the weight in grams of the dissolved inorganic matter in one kilogram of water (Stumm and Morgan, 1996). Most produced waters have salinities greater than that of seawater which ranged about $r 5,000$ ppm and, therefore, are denser than seawater (Collins, 1975). Sarir "C" fields produced water has a salinity of 154,000-205,317 ppm, Figure 6.

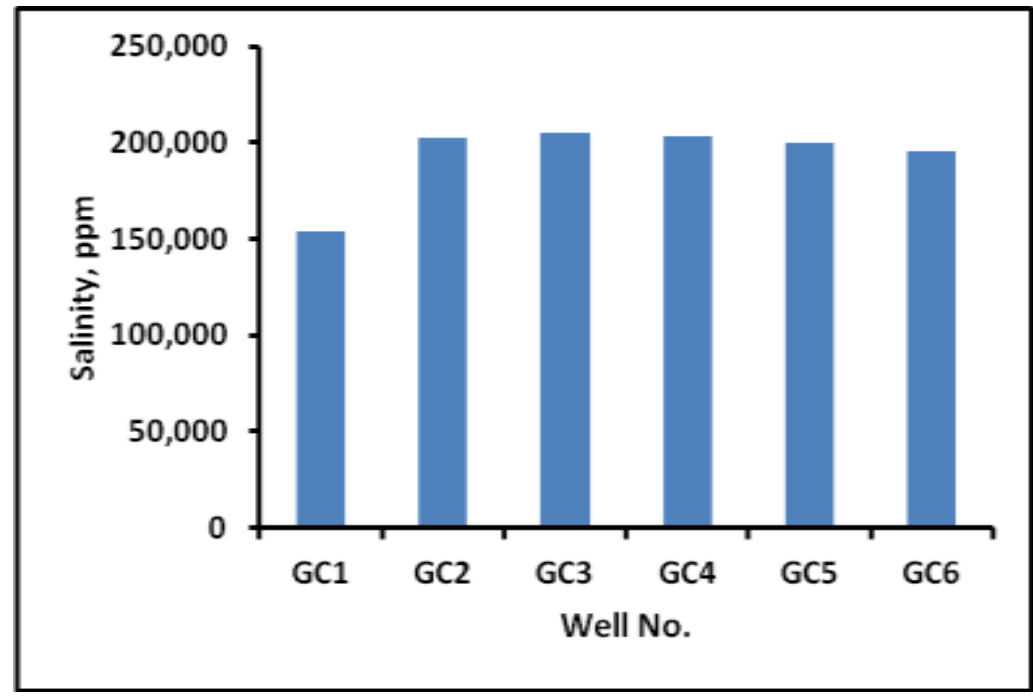

Fig. 6: Salinity of produced water from six wells in the Sarir "C" field.

Produced water contains the same salts as seawater, with sodium and chloride the most abundant ions. The most abundant inorganic ions in highsalinity produced water are, in order of relative abundance sodium, chloride, calcium, magnesium, potassium, sulfate, bromide and bicarbonate. Concentration ratios of many of these ions are different in seawater and produced water, possibly contributing to the aquatic toxicity of produced water (Pillard, et al., 1996). The important ones represented by sodium and chloride exhibit very high concentration. Sodium concentration reaches 
59,342 ppm in GC-2 as highest value and 42,989 ppm as lowest value in GC-

1 , as well as chloride shows 93,378 ppm in GC1 and 124,284 ppm in GC-3 respectively as shown in Figures $7 \& 8$.

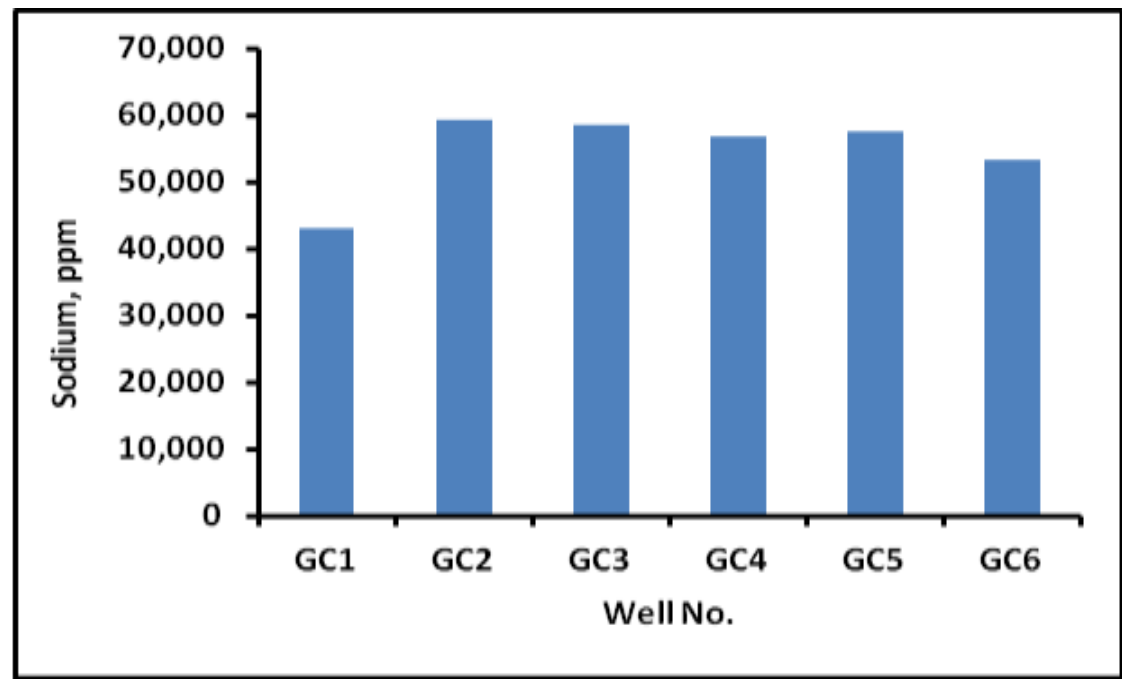

Fig. 7: Sodium concentrations (ppm) of produced water from six wells in the Sarir "C" fields.

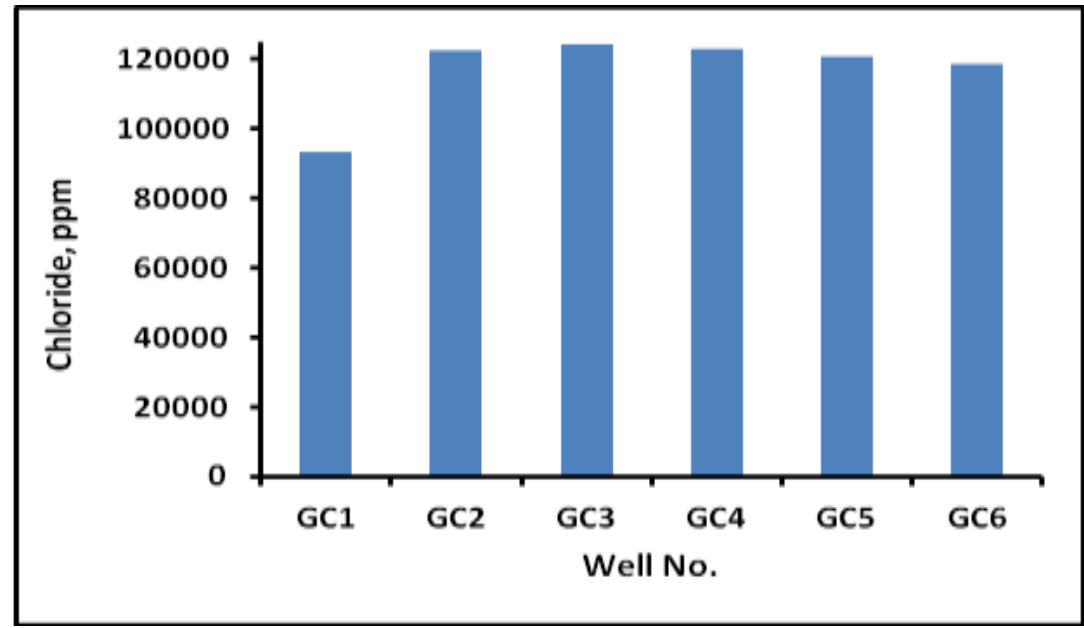

Fig. 8: Chloride concentrations (ppm) of produced water from six wells in the Sarir "C" fields. 
2. Heavy metal concentration: Produced water may contain several metals in dissolved or microparticulate forms. The type, concentration, and chemical species of metals in produced waters from different sources is variable, depending on the age and geology of the formations from which the oil and gas are produced (Collins, 1975) and the amount and inorganic chemical composition of flood water injected into the hydrocarbon reservoir. A few metals may be present in produced waters from different sources at concentrations substantially higher (1,000-fold or more) than their concentrations in clean natural seawater. The metals most frequently present in produced water at elevated concentrations, relative to those in seawater, include barium, iron, manganese, mercury, and zinc (Neff et al., 1987).

Because produced water is anoxic, iron and manganese may be present in solution at high concentrations which is agreement with our results in the six wells as indicated in Figures $9 \& 10$. The Iron concentration ranges from 94 ppm in GC-4 and 220 ppm in GC-6 while manganese ranges from 63 ppm in GC-1 \& GC-2 and 90 ppm for in GC-4. When formation waters containing high concentrations of these metals are brought to the surface and exposed to the atmosphere, the iron and manganese precipitate as iron and manganese oxyhydroxides. Several other metals in produced water may co-precipitate with iron and manganese and be dispersed, adsorbed to, or complexed with very fine solid hydrous $\mathrm{Fe}$ and $\mathrm{Mg}$ oxides in the receiving waters (Lee, et al., 2005; Azetsu-Scott et al., 2007). 


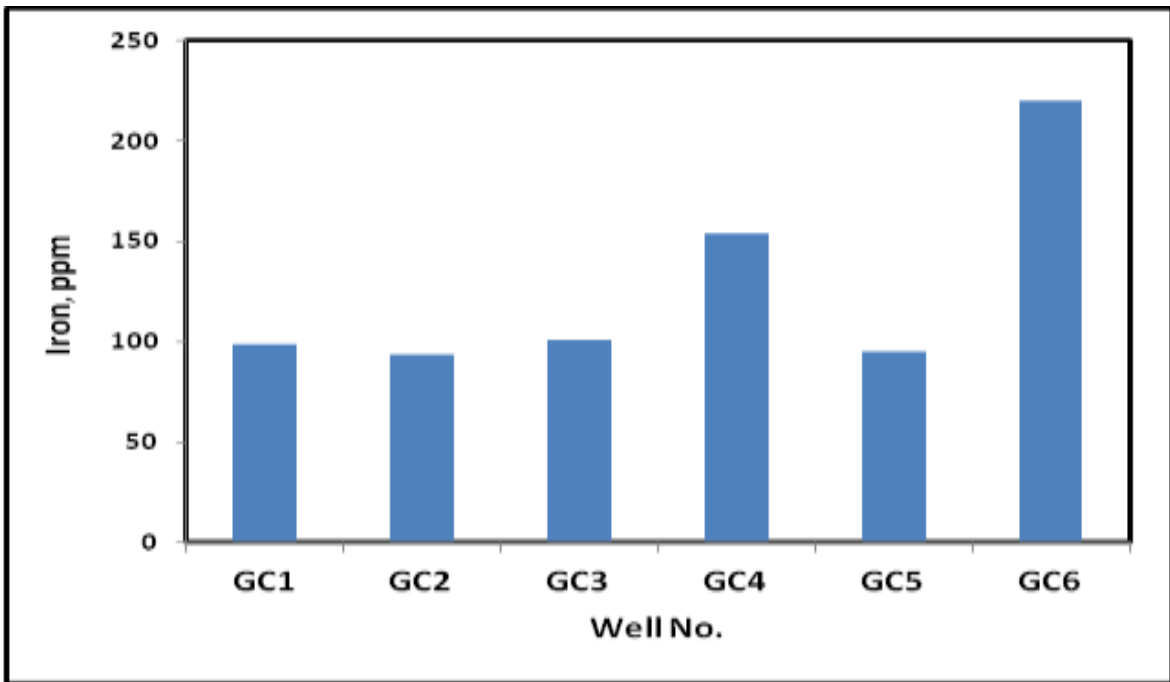

Fig. 9: Iron concentration (ppm) of produced water from six wells in the Sarir "C" fields.

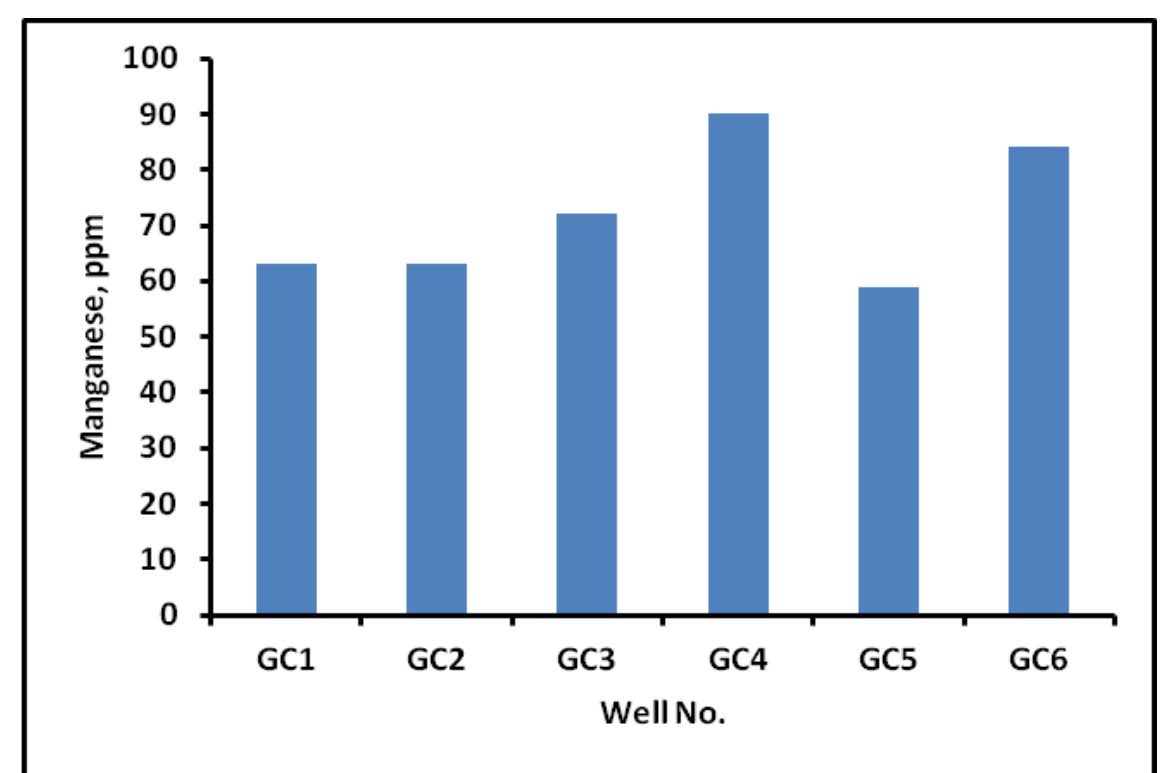

Fig. 10: Manganese concentration (ppm) of produced water from six wells in the Sarir "C" fields. 
3. Oil and grease: Most environmental regulatory agencies in countries that have significant offshore oil and gas production set limits on the concentrations of petroleum (usually measured as total oil and grease) that can be present in produced water destined for ocean discharge. Table 2 summarizes examples of limits imposed by different countries on total oil and grease or total petroleum hydrocarbon concentration in produced water destined for ocean discharge.

Table 2: Monthly average and daily maximum concentrations $(\mathrm{mg} / \mathrm{L})$ of total oil and grease permitted by several countries for produced water destined for ocean disposal (Veil, 2006).

\begin{tabular}{|l|c|c|}
\hline \multicolumn{1}{|c|}{ Country } & Monthly average & Daily maximum \\
\hline \hline Canada & 30 & 60 \\
\hline USA & 29 & 42 \\
\hline OSPAR (NE Atlantic) & 30 & - \\
\hline Mediterranean Sea & 40 & 100 \\
\hline Western Australia & 30 & 50 \\
\hline Nigeria & 40 & 72 \\
\hline Brazil & - & 20 \\
\hline
\end{tabular}

Under the 2002 Offshore Waste Treatment Guidelines, the hydrocarbon concentration of produced water must be reduced to acceptable levels prior to discharge into the ocean (NEB, 2002).

Figure 11 showed that, the GC-1 and GC-5 contain the higher concentration of the oil and grease which contains $55 \mathrm{ppm}$, while the lowest concentration is $40 \mathrm{ppm}$ in GC-3. 


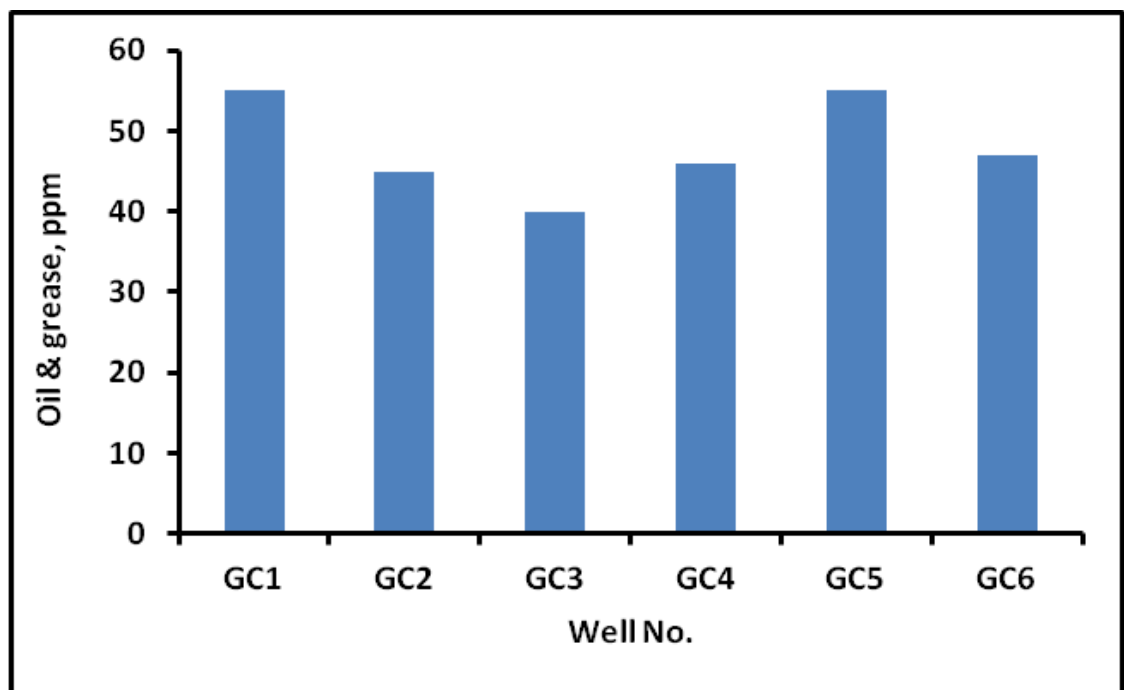

Fig. 11: Oil and grease concentrations (ppm) of produced water from six wells in the Sarir "C" fields.

\section{CONCLUSIONS}

This study has shown that some physico-chemical properties of produced water from Sarir "C" oil fields are higher than the stipulated regulatory limit for discharge into the environment. Total dissolved solids and some other parameters are still very high, continuous discharge of these produced water without adequate treatment will further damage our fragile environment. It is therefore recommended that adequate treatment, monitoring and re-use as industrial process water plan for produced water in the Sirt basin be put in place to ensure compliance with best global practices. It can be concluded that, untreated produced water discharges may be harmful to the surrounding environment. Hence, these large amounts of disposal water must be treated before drainage in the surrounding medium or reinjected into reservoir formations. 
J. Environ. Sci.

Institute of Environmental Studies and Research - Ain Shams University

\section{REFERENCES}

APHA (1995): Standard Methods for the Examination of Water/Wastewater. APHA-AWWA-WPCF, Washington D. C. 20036.

Arowoshola, L., Cope, G.; David, V.; Gasson, C.; Gonz_alez-Manch_on, C., Kelleher, M., Lang, H., Uzelac, J. (2011), Produced Water Market. Opportunities in the Oil, Shale and Gas Sectors in North America. A Global Water Intelligence publication.

ASTM (1979): Annual Book of America Society for Testing and Materials Standards, 1527, Philadelphia.

Azetsu-Scott, K., Yeats, P., Wohlgeschaffen, G., Dalziel, J., Niven, S., Lee, K. (2007): Precipitation of heavy metals in produced water: influence on contaminant transport and toxicity. Mar. Environ. Res. 63:146-167.

Carmalt, S.W. and John, B. St. (1986): Giant oil and gas fields, in Future Petroleum Provinces of the World: AAPG Memoir 40, p.. 11-53.

Collins, A.G. (1975): Geochemistry of oilfield waters. Elsevier, New York, $496 \mathrm{pp}$.

Gillespie, J. and Sanford, R.M. (1967): The geology of the Sarir oil field, Sirte Basin, Libya, in Proceedings $7^{\text {th }}$ world Petroleum Congress, v.2, p. 181-193.

Guerra, K., Dahm, K., Dundorf, S. (2011): Oil and Gas Produced Water Management and Beneficial Use in the Western United States. Science and Technology Program Report, p. 157.

Khatib, Z. and Verbeek, P. (2003): Water to Value - Produced Water Management for Sustainable Field Development of Mature and Green Fields, in Society of Petroleum Engineers.

Lee, K.; Azetsu-Scott, K., Cobanli, S.E.; Dalziel, J., Niven, S., Wohlgeschaffen, G., Yeats, P. (2005): Overview of potential impacts of produced water discharges in Atlantic Canada. In: Armworthy SL, Cranford PJ, Lee K (eds) Offshore oil and gas environmental effects monitoring: approaches and technologies. Battelle Press, Columbus, OH, pp 319-342, 631. 
NEB (National Energy Board of Canada) (2002): Offshore waste treatment guidelines. Offshore chemical selection guidelines for drilling \& production activities on Frontier Lands. National Petroleum Board, Canada-Nova Scotia Offshore Petroleum Board, CanadaNewfoundland and Labrador Offshore Petroleum Board. Calgary, Alberta, Canada, 23 pp

Neff, J.M. (1987): Biological effects of drilling fluids, drill cuttings and produced waters. In: Boesch DF, Rabalais NN (eds) Long-term effects of offshore oil and gas development. Elsevier Applied Science Publishers, London, pp 469-538.

Pillard, D.A., Tietge, J.E., Evans, J.M. (1996): Estimating the acute toxicity of produced waters to marine organisms using predictive toxicity models. In: Reed M, Johnsen S (eds) Produced water 2. Environmental issues and mitigation technologies. Plenum Press, New York, pp 49-60.

Stumm, W. and Morgan, J.J. (1996): Aquatic Chemistry: Chemical Equilibria and Rates in Natural Waters. New York: Wiley.

Veil, J.A. (2006): Comparison of two international approaches to controlling risk from produced water discharges. Paper presented at the 70th PERF meeting, Paris, France, March 21-22, 2006. 


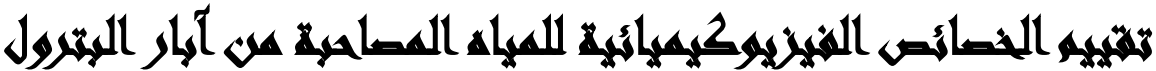

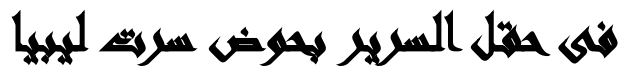

[1]

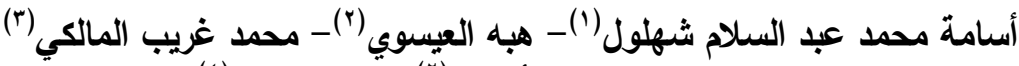

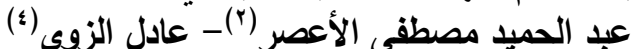

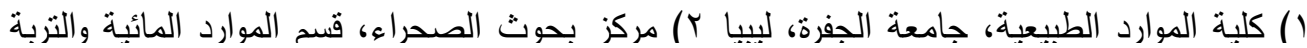

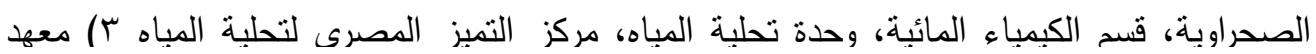

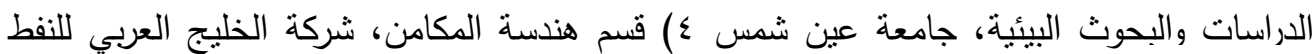
(اجوكو)، ليبيان

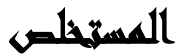

يصاحب إنتاج النفط والغاز كميات كبيرة من المياه المنتجة. يتم فصل المياه المنتجة من النفط

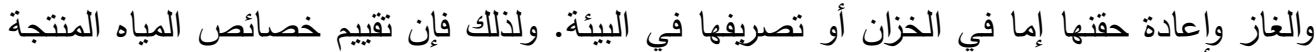

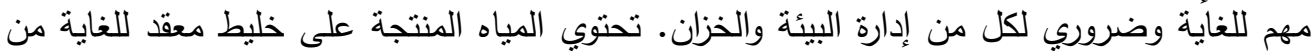

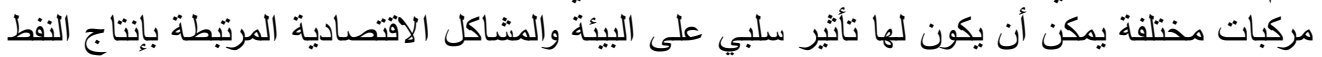

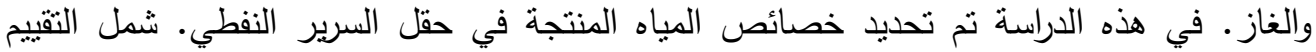

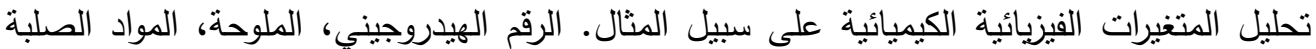

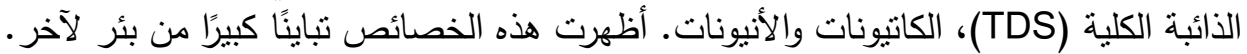

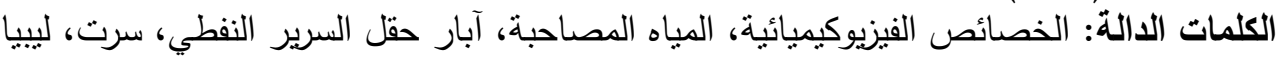

